\title{
Do closeness, support, and reciprocity influence trust in friendship?
}

\author{
Muh. Reza Firmansyah, Faturochman \& Wenty Marina Minza \\ Center for Indigenous and Cultural Psychology, Universitas Gadjah Mada, Sleman, Yogyakarta
}

\begin{abstract}
Prior qualitative research by Faturochman and Minza (2014) on trust in Indonesia found that trust is influenced by relational attributes, including closeness, support, and reciprocity. This study aims to examine whether the findings of the previous research can be applied in specific forms of relationships, e.g. friendship. The survey method is used in this study, involving 97 males and $123(\mathrm{~N}=220)$ females who completed a scale related to the variables studied. We found that support and reciprocity significantly predicted the score of trust. However, closeness did not. It was also found that the effect of support is higher than reciprocity. Based on the research, we created the regression model with the contribution of support to the trust $37.8 \%$, then reciprocity addition which was analyzed together with support gave a total contribution to the trust $41.5 \%$. The implication of this study is further discussed.
\end{abstract}

Keywords: closeness, friendship, reciprocity, support, trust

\begin{abstract}
Abstrak
Penelitian kualitatif sebelumnya yang dilakukan oleh Faturochman dan Minza (2014) terkait kepercayaan di Indonesia menemukan bahwa kepercayaan dipengaruhi oleh atribut relasional, termasuk kedekatan, dukungan, dan resiprositas. Penelitian ini bertujuan untuk menguji pengaruh atribut relasional terhadap kepercayaan dalam relasi pertemanan. Metode survei digunakan dalam penelitian ini, melibatkan 97 laki-laki dan 123 perempuan $(\mathrm{N}=220)$ yang mengisi skala terkait dengan variabel yang diteliti. Analisis keseluruhan variabel independen menemukan bahwa dukungan dan resiprositas secara signifikan mempengaruhi kepercayaan, namun tidak dengan kedekatan. Lebih lanjut lagi, hasil dari penelitian ini ditemukan bahwa pengaruh dukungan lebih tinggi daripada resiprositas. Berdasarkan temuan tersebut, kami membangun model regresi dengan kontribusi dukungan terhadap kepercayaan sebesar 37,8\%, kemudian penambahan resiprositas yang dianalisis secara bersamaan dengan dukungan memberikan total kontribusi terhadap kepercayaan sebesar 41,5\%. Implikasi dari penelitian ini kemudian dibahas lebih lanjut.
\end{abstract}

Kata Kunci: dukungan, kedekatan, kepercayaan, pertemanan, resiprositas

\section{Introduction}

Some works of literature have stated that friendship provides many advantages for building a healthier life. People having strong trusting friendships have greater social support and hence a better quality of life (Campbell, Holderness, \& Riggs, 2015; Lunsky \& Benson, 2001; Warris \& Rafique, 2009). Poulin and Chan (2010) also explained the benefits of friendship, which play a key role in human personal competence and identity, allows different types of social support (e.g. emotional, instrumental; Berndt, 1989), influences youth behaviors, goals, and attitudes through modeling or peer pressure (Berndt \& Murphy, 2003), and even provides a unique socialization context for the acquisition of essential social skills (e.g. sharing, conflict resolution; de Wied, Branje, \& Meeus, 2007; Salvas, et al., 2014). Fukuyama also emphasizes that the amount of trust in non-kin relationships (friendships) is ultimately the key to the progress of large corporations (Warris \& Rafique, 2009).

The significance of friendships in human relationships has lead researchers to develop studies on this topic. A good friendship is typically characterized by the importance of affection, intimacy, reliable alliance, and instrumental and emotional support (Berndt \& Murphy, 2003; Bukowski \& Hoza, 1989; Zimmermann, 2004). Despite those, the importance of the above aspects in friendship, Zimmermann (2004) also emphasizes that there is empirical evidence that not all adolescents have friendships that are characterized by mutuality and trust. This type of
Naskah masuk: 2 Januari 2020

Naskah diterima: 15 Agustus 2020
*Center for Indigenous and Cultural Psychology, Universitas Gadjah Mada Jl. Sosio Humaniora No.1, Kabupaten Sleman, D. I. Yogyakarta 55281 E-mail: firmansyahreza.m@gmail.com 
friendships need to be improved by developing interpersonal trust throughout the process.

Warris and Rafique (2009) emphasized that trust and friendship are closely-related constructs. They have also found that there is a significant positive correlation between trust and friendship. Friendship cannot be developed without trust (Warris \& Rafique, 2009), meaning that trust has a significant role in relationships to support the fulfillment of needs. Trust has a positive impact on a relationship, which will facilitate the growth of the relationship. As in other relationships, mutual trust is a must to avoid pain and betrayal. A previous study from Anatassia and Faturochman (2014) found that as many as 71\% of friends have been betrayed.

Missing from the literature is the answer to the question of whether each dimension of relational quality can shape trust. Prior research by Faturochman and Minza (2014) described that trust and trustworthiness are not only shaped by personal attributes or disposition because there is interactional and relational orientation at play. Therefore, trust is may be predicted by relational attributes. Faturochman and Minza (2014) found the relational attributes-namely, closeness, support, and reciprocity - and they play a significant role in trust. Closeness, in this case, is not defined as physical or in quantitative degree but defined as being close emotionally. Support as a relational context in trust can be described as being open, understanding, assuring, respectful, and offering love, while reciprocity can be defined as mutual and cooperative action in a relationship.

It is possible that not all relational attributes predict trust in friendship. Here, cultural context may matter. Although personal dispositions such as social skills were claimed to positively affect friendship quality (Demir, Jaafar, Bilyk, \& Mohd Ariff, 2012), the relational dynamics and the interpersonal processes may vary across cultural context (Korn, 1993). Thus, our paper aim to investigate whether relational attributes may influence trust in Indonesian context.

\section{Defining Trust and the Source of Trust}

Evolutionary theory states that social needs will increase along with individuals' growth. This is the reason why humans form self-defense mechanisms by establishing relationships in the form of affiliations to obtain help from others, to build closeness and establish intimacy, share sexual intimacy, and so on (Kenrick \& Shiota, 2008; Neuberg, Kenrick, \& Schaller, 2010). To fulfill the social needs, there is a requirement to establish a trustworthy sense of unity under the assumption that people will help when we ask for help. This is the basis of relationships in the form of affiliations (Sears, Freedman, \& Peplau, 2006). With one and another, as a part of selfdefense, human need trust for it to work well and survived (Simpson, 2007), because trust is a general belief about another person's trustworthiness with benevolence that emerges under conditions of unknown outcomes (Robbins, 2016a, 2016b). Thus, trust is a fundamental aspect in social life especially in an interpersonal relationship (Igarashi, et al., 2008). A secure base build by trust, also intimacy, and positive interpersonal expectancies, including increases in perceived responsiveness and available support, all social processes including interpersonal relationships are supported by trust (Gable, Gosnell, Maisel, \& Strachman, 2012). Warris and Rafique (2009) found that the key to positive interpersonal relationships in various settings is trust because it is central to how we interact with others. A relationship will have higher chances of survival when trust is involved.

There was an ever-changing description of trust. Rempel, Holmes, and Zanna (1985) concluded trust as the feelings of confidence and security in the caring responses of the partner and the strength of a relationship. He also cited Scazoni (1979) mentioning that trust requires a willingness to place oneself in a position of risk. It is not easy to have confidence in the ability of another in a relationship. Trust enables actors (trustors) to do a "leap of faith" even for any reason whether it can guarantee trust or not at all. In such a leap, the actor (trustor) ignores doubt that the actions of others can harm him, or in other words, "a leap of faith" can be referred to as "positive expectation" by the actor (trustor) as a prerequisite for the effectuation of trust, so as long as trust lasts, "leap of faith" is possible (Bijlsma-Frankema, Sitkin, \& Weibel, 2015). Trust is essential in relationships and life satisfaction, it is important to understand the role of trust in social relationships (Amati, Meggiolaro, Revelini, \& Zaccarin, 2018).

Many researchers have been conducted to investigate the sources of trust (e.g. Deutsch, 1958, 1962; Kelley \& Thibaut, 1979; Mayer, Davis, \& Schoorman, 1995; Simpson, 2007). Generally, trust is seen as an individual generalization of trust experience in local interaction or by the internal predisposition of trustworthiness to others and also stems from secure relationships with particular others (Igarashi, et al., 2008), this particularistic trust as conceptually related to relationism or mutually reinforce each other and supportive connectedness of oneself with others (Paxton \& Glanville, 2015; Robbins, 2016a, 2016b). Based on these, trust becomes a critical mechanism in all relationships, such as interpersonal relations 
(Koranyi \& Rothermund, 2012), educational relations (Tschannen-Moran, 2014), and even in organizational relations (Meng, 2015). Therefore, trust determines the quality of relationships at various levels of analysis in the context of relationships, including friendship (Firmansyah, Amelia, Jamil, \& Minza, 2019).

Mayer et al. (1995) are one of the main literature approaches conceptualizing interpersonal trust. Mayer explains three criteria that make a person trusted namely one's ability, integrity, and benevolence. He explains that ability is a group of skills, competencies, and characteristics that enable a party to influence within some specific domain. For instance, when someone can speak fluently and attractively, other people will trust him or her as a good person or communicator. While integrity is a set of principles in a trustee that the trustor finds acceptable. Someone who acts congruently with his or her words will be trusted. The third is benevolence, which has been defined as the extent to which a trustee is believed to want to do good to the trustor, aside from an egocentric profit motive. Although that reflects a belief that the trustee's orientation toward the trustor is important, the terms intentions and motives in it can include wider implications than the orientation towards the trustor. Furthermore, the research by Mayer et al. (1995) is interpreted as a personal quality of trust, which is called personal attributes by Faturochman and Minza (2014).

As mentioned before, Faturochman and Minza (2014) revealed that trust is influenced by relational attributes, included closeness, support, and reciprocity. However, the study covers a wide range of close relationships. The central question of this paper is whether relational attributes are important in developing generalized trust in friendships and if they are, which attributes are most influential. As Lestari, Faturochman, and Kim (2010) stated, trust is always inherent in social life, and people are adopted as a predisposition before action. However, high and low levels of trust depend on various things in social relations. Faturochman (2010) stated the category of the most trusted person in Indonesians' life. Mother became the most trusted person, followed by father, then a close friend. Therefore, this paper will examine the influence of relational attributes toward trust in a more specific relationship, that is, friendship.

\section{Research Method}

\section{Participants}

This study involves undergraduate students in Yogyakarta. Participants of this study consisted of 220 college students of Universitas Gadjah Mada, of which 116 participants are from the Faculty of Psychology and 104 participants are from the Faculty of Engineering. At the beginning of this research, the researcher only set the subject in the Faculty of Psychology UGM, however, there are very few male subjects in this faculty, according to this, the faculty of engineering was chosen with the assumption that it could increase male subject. They consist of $44,1 \%$ of males and $55,9 \%$ of females.

\section{Instrument}

Data were collected by survey method, where participants gathered in class while researchers distributed the questionnaires and instructed them to fill the paper-based scale. The scale was developed by Faturochman and Minza (2014) and examines relational attributes, including closeness $(\mathrm{N}=6, \alpha=0.90)$ such as "he/she is close with trustor", support ( $\mathrm{N}=5, \alpha=0.85)$ such as "he/she gives a suggestion to a trustor", and reciprocity ( $\mathrm{N}=5, \alpha=0.92)$ such as "he/she and trustor understand each other"; and trust ( $\mathrm{N}=6, \alpha$ $=0.74$ ) such as "I can fully trust my friend". In this study, trust acts as the dependent variable. The scale used a seven-point Likert scale (1 = strongly disagree to 7 = strongly agree). Data were analyzed using simple regression by SPSS version 21 .

\section{Data Analysis}

Data were analyzed using simple regression by SPSS version 21. Enter method in regression analysis was used to see how the influence of the independent variable $(\mathrm{X})$ on the dependent variable (Y), where the independent variable is relational attributes (support, reciprocity, and closeness) and the dependent variable is trust. After that, a sequential analysis was operated to see which independent variable has a greater contribution to trust. 
Table 1

Specification of the Scale

\begin{tabular}{llll}
\hline & N Item & Item-Correlation & $\boldsymbol{\alpha}$ \\
\hline Support & 6 & $0,50-0,75$ & 0,80 \\
Closeness & 5 & $0,72-0,83$ & 0,90 \\
Reciprocity & 5 & $0,71-0,84$ & 0,92 \\
Trust & 6 & $0,37-0,58$ & 0,74 \\
& & \\
\hline
\end{tabular}

\section{Research Result}

This study finds two main results. First, closeness does not influence trust. When three variables were analyzed toward trust, they contributed $41.5 \%\left(F=50.99 ; p<0,001 ; R^{2}=0,415\right)$. Table 2 below is the result of the regression analysis.

The result also shows that closeness has no significant value ( $p=0.981)$, so closeness was not further included in this model. When closeness was excluded, the contribution did not change at all ( $\left.F=76.84 ; \mathrm{p}<0,001 ; \mathrm{R}^{2}=41.5 \%\right)$. Second, the result of simple regression by SPSS version 21 shows that the most influential variable among three relational variables is support $\left(F=132,62 ; p<0,001 ; R^{2}=0,378\right)$. Reciprocity only contributes $31.5 \%$ toward trust $\left(\mathrm{F}=76,84 ; \mathrm{p}<0,001 ; \mathrm{R}^{2}=0,315\right)$.

When those variables are analyzed based on their sequences (table 3), where reciprocity is added after support, the model increases $\left(F=76,84 ; p=0,001 ; R^{2}=41,5 \%\right)$. This shows that reciprocity contributes $3.7 \%$ more towards trust. But when reciprocity is added by support, the contribution changes from $31.5 \%$ to $41.5 \%$. From this analysis, support contributes $10 \%$ to reciprocity. This data shows that support has a bigger role rather than reciprocity.

Table 2

The Result of Regression Analysis

\begin{tabular}{llllll}
\hline Independent Variable & Dependent Variable & $\boldsymbol{\beta}$ (Beta) & $\mathbf{F}$ & $\mathbf{p}$ & $\mathbf{R}^{2}$ \\
\hline Support & & 0,435 & & $0,00^{*}$ & \\
Reciprocity & Trust & 0,264 & 50,99 & $0,00^{*}$ & 0,415 \\
Closeness & & $-0,002$ & & $0,98^{\text {ns }}$ & \\
\hline
\end{tabular}

$* \mathrm{p}<0,001$

Table 3

The result of sequential analysis

\begin{tabular}{lccccc}
\hline \multicolumn{1}{c}{ Independent Variable } & Dependent Variable & $\mathbf{F}$ & $\mathbf{t}$ & $\mathbf{R}^{\mathbf{2}}$ & $\mathbf{R}^{\mathbf{2}}$ change \\
\hline Support & Trust & 132,62 & 11,52 & 0,378 & \multirow{2}{*}{0,037} \\
\cline { 1 - 5 } $\begin{array}{l}\text { Support } \\
\text { Reciprocity }\end{array}$ & Trust & \multirow{2}{*}{76,84} & 6,07 & \multirow{2}{*}{0,415} & \\
\hline
\end{tabular}

\section{Discussion}

Faturochman and Minza (2014) have found that trust is influenced by closeness, support, and reci-procity. In this study, only support and reciprocity have a significant role in influencing trust. It has been explained earlier that support is defined as the determinant of the quality of life and it encourages individual confidence levels (Craddock, 1996; Lunsky \& Benson, 2001; Newsom \& Schulz, 1996). Individuals trust their friends by observing their friends' motivation orientation to support them, partner's support also increases, and individual's self-esteem
(Simpson, 2007). Afifi, Afifi, Merrill, Denes and Davis (2013) argued that support beco-mes the main predictor of satisfaction in friend-ship. Then, Salazar (2015) said that friends need support especially to improve their selfacceptance, by the support, people are easier to gain confidence in friendship relations.

Support can be defined as being cared for, loved, and appreciated (Cobb, 1976), that's why support has a positive impact to influence trust. Support is also a part of affection between indivi-duals in a relationship (Salazar, 2015) and is asso-ciated with closeness (Baumeister, Vohs, DeWall, \& Zhang, 2007). In the other words, 
support can be regarded as real evidence of closeness in a friend-ship (Karney \& Bradbury, 1995). In addition, Rahmanawati, Ferdian, Widyastuti, Faturochman, Minza (2020) stated that closeness is only needed when a relationship started, while support and reciprocity are needed to keep the relationships going. The above arguments are parallel to our results, explaining why closeness is statistically not significant. In friendship, support is highly valued. Thus, we can expect the level of closeness in friend-ships through the support offered in that relation-ship (Rodebaugh et al., 2014; Steptoe, Shankar, Demakakos, Wardle, 2013).

In Faturochman and Minza (2014), trust is influenced by closeness; while in this study, close-ness does not play its role in trust. This could be due to the wide scope of research in the previous study, close relationship. While this study focuses on friendship relationship. Faturochman (2010) stated that in Indonesian life, mothers are the most trusted people, followed by fathers and close friends. In a friendship relationship, closeness is defined as support. In a family relationship (mother and father), closeness is a manifestation of attachment (Campbell \& Stanton, 2019; van de Rijt \& Buskens, 2006). Attachment in the family is the initial part of a person's life-span, which is described as a sense of security and insecurity. This sense then predicts trust (Campbell \& Stanton, 2019).

Closeness does not influence trust because support has illustrated the existence of closeness as the basis of friendship. In friendship, there are experiences of togetherness and communication with each other as a part of support (not as a part of closeness), which is togetherness and communi-cation to each other has a big contribution to the quality and quantity of a person's life journey. In other words, closeness and support have similar work mechanisms in friendships (Shockley-Zalabak \& Ellis, 2006). These arguments show that closeness is not one of the main predictors in influencing trust in friendship. although trust depends on the relationship between closeness, familiarity, and risk perception (Losee \& Joslyn, 2018).

Reciprocity also plays a role in influencing trust, especially in friendship (Berscheid \& Regan, 2016). Because trust is the willingness to accept vulnerability, trust evolves throughout the relation-ship through repeated action and a history of reciprocity (Burke, Sims, Lazzara, \& Salas, 2007). Reciprocity often takes form in mutual acts of giving and receiving kindness or benevolence in a relationship (Foddy, Platow, \& Yamagishi, 2009). Robbins (2016a, 2016b) also noted the presence of reciprocity, and the importance of balance concern-ing trust relations. Based on research by Lusher, Kremer, and Robins (2014), there was a significant and positive effect for reciprocity on trust, they illustrated trust as formed through experience of togetherness and similar experiences, which is can be obtained in friendship.

Trust is generally seen as reciprocal (Burt \& Knez, 1995; Gambetta, 1988; McEvily, Perrone, \& Zaheer, 2003), specifically as an expectation that others will reciprocate such behavior (Kramer \& Tyler, 1996). According to Blau (1964), reciprocity is a universal human belief and human activity, rep resenting social exchange. This should happen because in trust there are risks and uncertainties (Jones \& George, 1998), risks and uncertainties in trust lead to an expectation that trust is recipro-cated as a psychological heuristic that can be used to resolve risks and uncertainties as to the trust problem (Lusher, Kremer, \& Robins, 2014).

Reciprocity is the most general form of friendship, also called equality matching. Equality matching is a relationship based on the principle of balance, reciprocity, or compensation between the two parties involved in the relationship (Rai \& Fiske, 2011). This relation emphasizes the equal distribu-tion between giving and receiving. People focus on balance, namely by responding to what they receive from others, resulting in good social relationships. How reciprocity is constructed and acted upon is related to the moral and social norms in the local community (Fiske, 1992). Therefore, the balance emphasized in this relation, is derived from the rules of the community, used to avoid undesirable situations. This motif serves to maintain the balance depicted in take-and-give with the same scale in social relations (Rai \& Fiske, 2011).

Social norms based on equality matching are easily found in Asian regions, including in Indonesia where moral equality or equality motives are deemed important. The motives for equality are based on the awareness of reciprocity with each other. This also explains why reciprocity has a sig-nificant role in trust in friendship relationships. Discussing reciprocity, there are two kinds of reci-procity, such as reciprocal benefit and reciprocal relation. Reciprocal benefit leads to an economic perspective with benefit as the main variable, but reciprocal relation leads to social perspective with relation as the main variable, two of these recipro-city concepts work differently in social life and based on the norm of reciprocity (Sun, Peng, Lim, \& Wang, 2014). On the other hand, Malmendier, te Velde, \& Weber (2014) said that 
in economic pers-pectives reciprocity occurs when the other party provides something (goods or services) and it is considered as a benefit but in social perspective, reciprocity's seen as a sharing behavior but it involves two sides. Involving two sides is the main thing that distinguishes reciprocity and prosocial behavior, furthermore, overall reciprocity arises based on external motives.

Trust in friendship will increase the willingness to contribute, and this effect is based on expectations of direct reciprocity in relations (Felletti \& Paglieri, 2019). Trust with reciprocity in relationships encourages people to cooperate (Balliet \& Van Lange, 2013). Apart from that, reciprocity and trust play a mutual role: trust is influenced by reciprocity, and trust can influence reciprocity in building and maintaining functions in a relationship (Kurzban, 2003; Ostrom, 2003).

Norms of reciprocity are a general social norm by building the basic concept of reciprocal relationships (Taylor, Peplau, \& Sears, 2009). It is no surprise that we found the significant presence of mutual trust ties, especially given that the reci-procal nature of trust is seen as fundamental to the definition of the trust itself. Reciprocity is a funda-mental structure for trust relations, especially in the collective climate in Indonesia. Eastern societies are found to be more trusting and more reciprocal (Yamagishi \& Yamagishi, 1994). The collective cli-mate has found in Eastern societies often creates social norms as guidance to determine the attitude and behavior of society.

A number of research have found a high value of collectivism in Indonesia when compared to individualism in western culture (e.g. Hofstede, 1991; Marshall, 1997). This comparison may be useful to explain individualism and collectivism friendship in variation across cultures. Anthro-pologists have described Javanese social structure where friendships are more focused on integration into communities or social networks, in other words, friendships in Indonesia are difficult to specify in terms of specific relationships because friendships in Indonesia are more focused on integ-ration into clique or community groups, and less focused on the development of close dyadic friend-ships relation like the US or the other western cul-ture (French, Pidada \& Victor, 2005; French, Bae, Pidada, \& Lee, 2006).

Indonesians do not describe friendship as the closeness of a relationship. It seems that build-ing a social harmonious condition is more impor-tant for the Indonesian people. Making friends with everyone is encouraged-even if the relationship is not close, because the main goal of a social relation-ship is to maintain harmony
(French, Pidada \& Victor, 2005; French, Bae, Pidada, \& Lee, 2006). Thus, the concept of 'friend' is used to describe a wide variety of friendships as, for example, class-mates still are called "friends" even though not in close relationships, as well as friendship with social structures in other places, such as friendship in the neighborhood, to friends in other social environments. In short, the above studies make clear that being close may be irrelevant for friendship formation in the Indonesian context because the social norms encourage them to accept everyone as their friend.

\section{Conclusion}

Trust should not be regarded as a single factor but a series factor with causal relationships, especially in friendship. Trust in friendship is influenced by relational attributes, but the relational attributes that matter are support and reciprocity. The sup-port contributes more toward trust, in comparison to reciprocity. Closeness does not play a significant role in trust in friendship. Closeness may play an important role in friendship, but it is not enough to influence trust in friendships. The implication shows that the trustor prefers to have a friend with a high level of support, it is better if support and reciprocity are able in friendship.

\section{Limitation and Suggestion}

The results of this study indicate that offer-ing support is significant in building trust in friend-ship. Thus, to strengthen friendship in collective societies such as Indonesia, proactive behavior to provide positive support and conduct reciprocal behavior is encouraged. This research only focused on friendship relation, so need to further research that looking at trust models in the different relation context, for example, trust in family relation, political relation, or in work relation, might find the different result and not to mention the emergence of new variables.

\section{References}

Afifi, T., Afifi, W., Merrill, A. F., Denes, A., \& Davis, S. (2013). "You need to stop talking about this!": Verbal rumination and the costs of social support. Human Communication Research, 
39(4), 395-421.

https://doi.org/10.1111/hcre.12012

Amati, V., Meggiolaro, S., Rivellini, G., \& Zaccarin, S. (2018). Social relations and life satisfaction: The role of friends. Genus, 74(1), 7. https://doi.org/10.1186/s41118-018-0032$\mathrm{z}$

Anatassia, D. F., \& Faturochman. (2014). Pencederaan kepercayaan pada relasi persahabatan remaja [Tesis]. Universitas Gadjah Mada

Balliet, D., \& Van Lange, P. A. M. (2013). Trust, conflict, and cooperation: A meta-analysis. Psychological Bulletin, 139(5), 1090-1112. https://doi.org/10.1037/a0030939

Baumeister, R. F., Vohs, K. D., DeWall, C. N., \& Zhang, L. (2007). How emotion shapes behavior: Feedback, anticipation, and reflection, rather than direct causation. Personality and Social Psychology Review, 11(2), 167-203. https://doi.org/10.1177/108886830730103 3

Berndt, T. J. (1989). Obtaining support from friends during childhood and adolescence. In Children's Social Networks and Social Supports (pp. 308-331). John Wiley \& Sons, Inc.

Berndt, T. J., \& Murphy, L. M. (2003). Influences of friends and friendships: Myths, truths, and research recommendations. In Advances in Child Development and Behavior (Vol. 30, pp. 275-310). Elsevier. https://doi.org/10.1016/S00652407(02)80044-1

Berscheid, E., \& Regan, P. (2016). The psychology of interpersonal relations. Routledge.

Bijlsma-Frankema, K., Sitkin, S. B., \& Weibel, A. (2015). Distrust in the balance: The emergence and development of intergroup distrust in a court of law. Organization Science, 26(4), 1018-1039. https://doi.org/10.1287/orsc.2015.0977

Blau, P. M. (1964). Justice in social exchange. Sociological Inquiry, 34(2), 193-206. https://doi.org/10.1111/j.1475682X.1964.tb00583.x

Bukowski, B., William M., \& Hoza, B. (1989). Popularity and friendship: Issues in theory, measurement, and outcome. In Wiley series on personality processes: Peer relationships in child development. John Wiley \& Sons.

Burke, C. S., Sims, D. E., Lazzara, E. H., \& Salas, E. (2007). Trust in leadership: A multi-level review and integration. The Leadership Quarterly, 18(6), 606-632. https://doi.org/10.1016/j.leaqua.2007.09.00 6

Burt, R. S., \& Knez, M. (1995). Kinds of third-party effects on trust. Rationality and Society, 7(3),
255-292.

https://doi.org/10.1177/104346319500700 3003

Campbell, K., Holderness, N., \& Riggs, M. (2015). Friendship chemistry: An examination of underlying factors. The Social Science Journal, 52(2), 239-247. https://doi.org/10.1016/j.soscij.2015.01.00 5

Campbell, L., \& Stanton, S. C. (2019). Adult attachment and trust in romantic relationships. Current Opinion in Psychology, 25 , 148-151. https://doi.org/10.1016/j.copsyc.2018.08.0 04

Cobb, S. (1976). Social support as a moderator of life stress. Psychosomatic Medicine, 38(5), 300.

Craddock, A. E. (1996). Relational resources as buffers against the impact of stress: A longitudinal study of seminary students and their partners. Journal of Psychology and Theology, 24(1), 38-46. https://doi.org/10.1177/009164719602400 104

de Wied, M., Branje, S. J. T., \& Meeus, W. H. J. (2007). Empathy and conflict resolution in friendship relations among adolescents. Aggressive Behavior, 33(1), 48-55. https://doi.org/10.1002/ab.20166

Demir, M., Jaafar, J., Bilyk, N., \& Mohd Ariff, M. R. (2012). Social skills, friendship and happiness: A cross-cultural investigation. The Journal of social psychology, 152(3), 379-385.

Deutsch, M. (1958). Trust and suspicion. Journal of Conflict Resolution, 2(4), 265-279. https://doi.org/10.1177/002200275800200 401

Deutsch, M. (1962). Cooperation and trust: Some theoretical notes. In Nebraska Symposium on Motivation (pp. 275-320). Nebraska Press.

Faturochman. (2010). The role of inter-ethnic marriage on trust and caution. ASEAN Regional Union of Psychological Association (ARUPS) Conference, Kuala Lumpur.

Faturochman, \& Minza, W. M. (2014). Exploring personal and relational trustworthiness. Unpublished Manuscript.

Felletti, S., \& Paglieri, F. (2019). Trust your peers! How trust among citizens can foster collective risk prevention. International Journal of Disaster Risk Reduction, 36, 101082. https://doi.org/10.1016/j.ijdrr.2019.101082

Firmansyah, M. R., Amelia, R., Jamil, R. A., \& Minza, M. (2019). Benevolence, competency, and integrity: Which one is more influential o trust in friendships? 18(1), 15. 
Fiske, A. P. (1992). The four elementary forms of sociality: Framework for a unified theory of social relations. Psychological Review, 99(4), 689-723. https://doi.org/10.1037/0033295X.99.4.689

Foddy, M., Platow, M. J., \& Yamagishi, T. (2009). Group-based trust in strangers: The role of stereotypes and expectations. Psychological Science, 20(4), 419-422.

https://doi.org/10.1111/j.14679280.2009.02312.x

French, D. C., Bae, A., Pidada, S., \& Lee, O. (2006). Friendships of Indonesian, South Korean, and U.S. college students. Personal Relationships, 13(1), 69-81. https://doi.org/10.1111/j.14756811.2006.00105.x

French, D., Pidada, S., \& Victor, A. (2005). Friendships of Indonesian and United States youth. International Journal of Behavioral Development, 29(4), 304-313. https://doi.org/10.1080/016502505440000 80

Gable, S. L., Gosnell, C. L., Maisel, N. C., \& Strachman, A. (2012). Safely testing the alarm: Close others' responses to personal positive events. Journal of Personality and Social

Psychology, 103(6), 963-981.https://doi.org /10.1037/a0029488

Gambetta, D. (1988). Trust: The making and breaking of cooperative relationships. Basil Blackwell.

Hofstede, G. (1991). Empirical models of cultural differences. In Contemporary Issues in CrossCultural Psychology (pp. 4-20). Swets \& Zeitlinger Publishers.

Igarashi, T., Kashima, Y., Kashima, E. S., Farsides, T., Kim, U., Strack, F., Werth, L., \& Yuki, M. (2008). Culture, trust, and social networks. Asian Journal of Social Psychology, 11(1), 88101. https://doi.org/10.1111/j.1467-839X.2 007.00246.x

Jones, G. R., \& George, J. M. (1998). The experience and evolution of trust: Implications for cooperation and teamwork. The Academy of Management Review, 23(3), 531. https://doi.org/10.2307/259293

Karney, B. R., \& Bradbury, T. N. (1995). The longitudinal course of marital quality and stability: A review of theory, method, and research. Psychological Bulletin. https://doi.org/10.14515/monitoring.2016. 1.02

Kelley, H. H., \& Thibaut, J. W. (1979). Interpersonal relations: $A$ theory of interdependence. John Wiley \& Sons, Inc.

Kenrick, D. T., \& Shiota, M. N. (2008). Approach and avoidance motivation(s): An evolutionary perspective. In Handbook of Approach and Avoidance Motivation (pp. 273288). Psychology Press.

Koranyi, N., \& Rothermund, K. (2012). Automatic coping mechanisms in committed relationships: Increased interpersonal trust as a response to stress. Journal of Experimental Social Psychology, 48(1), 180185.

https://doi.org/10.1016/j.jesp.2011.06.009

Korn, C. J. (1993). Friendship formation and development in two cultures: Universal constructs in the United States and Korea. Interpersonal communication in friend and mate relationships, 61-78.

Kramer, R. M., \& Tyler, T. R. (1996). Trust in organizations: Frontiers of theory and research. (pp. ix, 429). Sage Publications, Inc.

Kurzban, R. (2003). Biological foundations of reciprocity. In Trust and reciprocity: Interdisciplinary lessons from experimental research (pp. 105-127). Russell Sage Foundation.

Lestari, S., Faturochman, F., \& Kim, U. (2010). Trust in parent-child relationship among undergraduates students: Indigenous Psychological Analysis. Jurnal Psikologi, 37(2), 140-152.

Losee, J. E., \& Joslyn, S. (2018). The need to trust: How features of the forecasted weather influence forecast trust. International Journal of Disaster Risk Reduction, 30, 95-104. https://doi.org/10.1016/j.ijdrr.2018.02.032

Lunsky, Y., \& Benson, B. A. (2001). Association between perceived social support and strain, and positive and negative outcome for adults with mild intellectual disability. Journal of Intellectual Disability Research, 45(2), 106114. https://doi.org/10.1046/j.1365-2788.2 001.00334.x

Lusher, D., Kremer, P., \& Robins, G. (2014). Cooperative and competitive structures of trust relations in teams. Small Group Research, 45(1), 3-36. https://doi.org/10.1177/104649641351036 2

Malmendier, U., te Velde, V. L., \& Weber, R. A. (2014). Rethinking reciprocity. Annual Review of Economics, 6(1), 849-874. https://doi.org/10.1146/annureveconomics-080213-041312

Marshall, G. (1997). Repositioning class: Social inequality in industrial societies. Sage 
Mayer, R. C., Davis, J. H., \& Schoorman, F. D. (1995). An integrative model of organizational trust. The Academy of Management Review, 20(3), 709-734. https://doi.org/10.2307/258792

McEvily, B., Perrone, V., \& Zaheer, A. (2003). Trust as an organizing principle. Organization Science, 14(1), 91-103. https://doi.org/10.1287/orsc.14.1.91.12814

Meng, X. (2015). The role of trust in relationship development and performance improvement. Journal of Civil Engineering and Management, 21(7), 845-853.

https://doi.org/10.3846/13923730.2014.89 3923

Neuberg, S. L., Kenrick, D. T., \& Schaller, M. (2010). Evolutionary social psychology. In S. T. Fiske, D. T. Gilbert, \& G. Lindzey (Eds.), Handbook of Social Psychology (p. socpsy002021). John Wiley \& Sons, Inc. https://doi.org/10.1002/9780470561119.so cpsy002021

Newsom, J. T., \& Schulz, R. (1996). Social support as a mediator in the relation between functional status and quality of life in older adults. Psychology and Aging, 11(1), 34-44. https://doi.org/10.1037/0882-7974.11.1.34

Ostrom, E. (2003). Trust and reciprocity: Interdisciplinary lessons from experimental research. Russell Sage Foundation

Paxton, P., \& Glanville, J. L. (2015). Is trust rigid or malleable? A laboratory experiment. Social Psychology Quarterly, 78(2), 194-204. https://doi.org/10.1177/019027251558217 7

Poulin, F., \& Chan, A. (2010). Friendship stability and change in childhood and adolescence. Developmental Review, 30(3), 257-272. https://doi.org/10.1016/j.dr.2009.01.001

Rahmanawati, A., Ferdian, F. R., Widyastuti, T., Faturochman, F., \& Minza, W. M. (2020). How do relational and personal attributes affect trust in adolescent friendship: An exploratory model. HUMANITAS: Indonesian Psychological Journal, 17(1), 1. https://doi.org/10.26555/humanitas.v17i1. 12700

Rai, T. S., \& Fiske, A. P. (2011). Moral psychology is relationship regulation: Moral motives for unity, hierarchy, equality, and proportionality. Psychological Review, 118(1), 57-75. https://doi.org/10.1037/a0021867

Rempel, J. K., Holmes, J. G., \& Zanna, M. P. (1985). Trust in close relationships. Journal of Personality and Social Psychology, 49(1), 95112. https://doi.org/10.1037/0022-3514.49. 1.95

Robbins, B. G. (2016a). From the general to the specific: How social trust motivates relational trust. Social Science Research, 55, 16-30. https://doi.org/10.1016/j.ssresearch.2015.0 9.004

Robbins, B. G. (2016b). What is trust? A multidisciplinary review, critique, and synthesis. Sociology Compass, 10(10), 972986. https://doi.org/10.1111/soc4.12391

Rodebaugh, T. L., Lim, M. H., Fernandez, K. C., Langer, J. K., Weisman, J. S., Tonge, N., Levinson, C. A., \& Shumaker, E. A. (2014). Self and friend's differing views of social anxiety disorder's effects on friendships. Journal of Abnormal Psychology, 123(4), 715-724. https://doi.org/10.1037/abn0000015

Salazar, L. R. (2015). Exploring the relationship between compassion, closeness, trust, and social support in same-sex friendships. The Journal of Happiness \& Well-Being, 3(1), 1529.

Salvas, M.C., Vitaro, F., Brendgen, M., Dionne, G., Tremblay, R. E., \& Boivin, M. (2014). Friendship conflict and the development of generalized physical aggression in the early school years: A genetically informed study of potential moderators. Developmental Psychology, 50(6), 1794-1807. https://doi.org/10.1037/a0036419

Scazoni, J. (1979). Social exchange and behavioral interdependence. In R. L. Burgess \& T. L. Huston (Eds.), Social exchange in developing relationships. Academic Press

Sears, D. O., Freedman, J. L., \& Peplau, L. A. (2006). Psikologi sosial ( Jilid 1). PT. Erlangga

Shockley-Zalabak, P., \& Ellis, K. (2006). The communication of trust. In The IABC Handbook of Organizational Communication: A Guide to Internal Communication, Public Relations, Marketing, and Leadership (1st ed). Jossey-Bass.

Simpson, J. A. (2007). Psychological foundations of trust. Current Directions in Psychological Science, 16(5), 264-268.

https://doi.org/10.1111/j.14678721.2007.00517.x

Steptoe, A., Shankar, A., Demakakos, P., \& Wardle, J. (2013). Social isolation, loneliness, and allcause mortality in older men and women. Proceedings of the National Academy of Sciences, 110(15), 5797-5801. https://doi.org/10.1073/pnas.1219686110

Sun, Y., Peng, Z., Lim, K., \& Wang, W. (2014). Norm of reciprocity, reciprocal benefits, and reciprocal relationships: $A$ revisit of the role of reciprocity in 
knowledge sharing. 35th International Conference on Information Systems: Building a Better World Through Information Systems, ICIS 2014, Auckland, New Zealand.

Taylor, S. E., Peplau, L. A., \& Sears, D. O. (2009). Psikologi Sosial. PT. Erlangga.

Tschannen-Moran, M. (2014). The Interconnectivity of Trust in Schools. In D. Van Maele, P. Forsyth, \& M. Van Houtte (Eds.), Trust and School Life. Springer, Dordrecht.

van de Rijt, A., \& Buskens, V. (2006). Trust in intimate relationships: The increased importance of embeddedness for marriage in the United States. Rationality and Society, 18(2), 123-156. https://doi.org/10.1177/104346310606331 9

Warris, A., \& Rafique, R. (2009). Trust in friendship: A comparative analysis of male and female university students. Bulletin of Education and Research, 31(2), 75-84.

Yamagishi, T., \& Yamagishi, M. (1994). Trust and commitment in the United States and Japan. Motivation and Emotion, 18(2), 129-166. https://doi.org/10.1007/BF02249397

Zimmermann, P. (2004). Attachment representations and characteristics of friendship relations during adolescence. Journal of Experimental Child Psychology, 88(1), 83-101. https://doi.org/10.1016/j.jecp.2004.02.002 